\title{
Exploratory Factor Analysis of Management Accounting Tools (MATs) in Libyan Manufacturing Companies
}

\author{
Abdelghani Masaud Ahmed, Syamsul Azri Abdulrahman, Mazuri Binti Abd \\ Ghani
}

To Link this Article: http://dx.doi.org/10.6007/IJARBSS/v11-i12/11610

DOI:10.6007/IJARBSS/v11-i12/11610

Received: 11 October 2021, Revised: 16 November 2021, Accepted: 30 November 2021

Published Online: 20 December 2021

In-Text Citation: (Ahmed et al., 2021)

To Cite this Article: Ahmed, A. M., Abdulrahman, S. A., \& Ghani, M. B. A. (2021). Exploratory Factor Analysis of Management Accounting Tools (MATs) in Libyan Manufacturing Companies. International Journal of Academic Research in Business and Social Sciences, 11(12), 1582-1594.

Copyright: (c) 2021 The Author(s)

Published by Human Resource Management Academic Research Society (www.hrmars.com)

This article is published under the Creative Commons Attribution (CC BY 4.0) license. Anyone may reproduce, distribute, translate and create derivative works of this article (for both commercial and non0-commercial purposes), subject to full attribution to the original publication and authors. The full terms of this license may be seen

at: http://creativecommons.org/licences/by/4.0/legalcode

Vol. 11, No. 12, 2021, Pg. $1582-1594$

http://hrmars.com/index.php/pages/detail/IJARBSS

JOURNAL HOMEPAGE

Full Terms \& Conditions of access and use can be found at http://hrmars.com/index.php/pages/detail/publication-ethics 


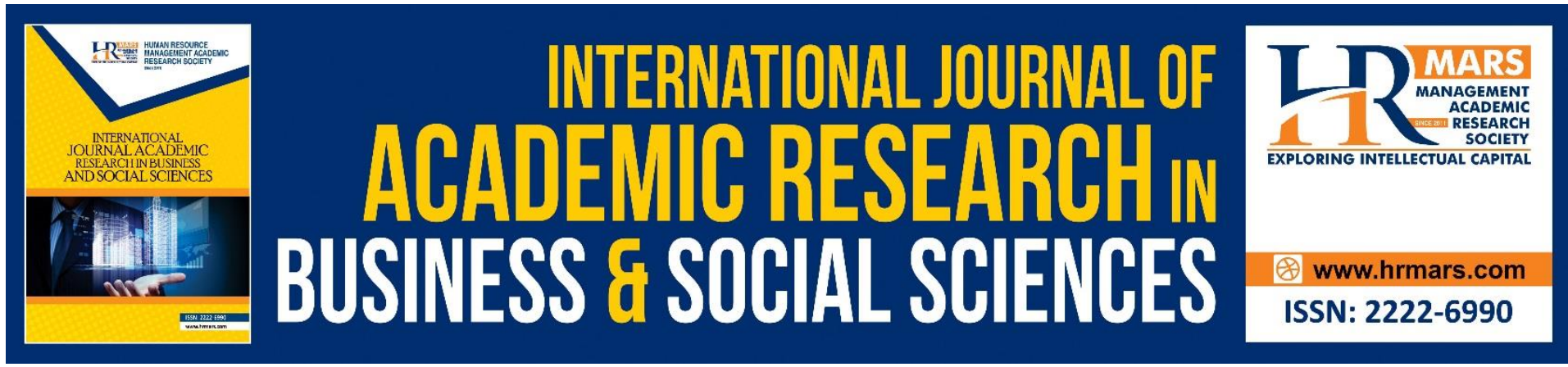

\title{
Exploratory Factor Analysis of Management Accounting Tools (MATs) in Libyan Manufacturing Companies
}

\author{
Abdelghani Masaud Ahmed, Dr. Syamsul Azri Abdulrahman, \\ Professor Dr. Mazuri Binti Abd Ghani
}

Faculty of Business and Management Sciences, University Sultan Zainal Abidin (UniSZA), Malaysia

\begin{abstract}
The purpose of this paper is to develop a reliable instrument to measure management accounting tools (MATs) through Exploratory Factor Analysis (EFA), particularly in Libyan manufacturing companies. 100 financial managers /accountants in Libyan manufacturing companies. IBM SPSS 24.0 tool has been used for statistical analyses. The reliability of the subscales from Cronbach Alpha is ranging from 0.833 to 0.896 . The results show that the Management accounting tools construct has three components or dimensions, i.e., adoption, (16 items), benefits (16 items), and the obstacles to the implementing of MATs ( 9 items). The factor loading for every item in each component is $>0.6$. The researcher applied the Cronbach Alpha test to check the internal reliability of the current MATs instrument was higher than 0.7 , which means that is reliable.
\end{abstract}

Keywords: Exploratory Factor Analysis (EFA), Management Accounting Tools (MATs).

\section{Introduction}

Management accounting tools promotes survival or organizations in the dynamic and competitive global markets by providing them with competitive advantage and guiding their managerial activities, motivating behaviours, supporting and creating cultural values needed for the strategic objectives realization (Hieu and Dung, 2018). Throughout the world, MATs have been garnering importance in practicing manager and policy maker circles in light of enhanced organizational performance (Ladislav, 2016). Evidently, the use of MATs have also increased through the years owing to factors effects in various phases of implementation based on the definition provided by IFAC of MA (Rufino, 2014).

\section{Management Accounting Tools (MATs)}

The International Management Accounting Practice Statement No 1 (IMAPS1), concerning Management Accounting Concepts established by the International Federations of Accounting in (IFAC, 2002) referred to management accounting as that portion of the process of management that is concerned with the use of organizational resource and of managerial processes and technologies that are concerned with contributing value to the organization 
through the achievement of effective resources use in the context of dynamism and competitiveness (IFAC, 2002). Moreover, the CIMA (2013) referred to a management accounting tool as a framework, model, technique or process enabling management accountants to enhance performance, facilitate decision-making, support strategic goals and objectives and contribute value.

\section{Motivation of the Study}

According to Sreekumar (2015), there is a considerable potential for developing nations to provide distinct opportunity for researchers to examine MATs evaluation in short-term. However, only a few empirical studies have been conducted in developing nations, particularly in the North African region. Tun Mat \& Smith (2014) revealed that MATs generally differ from one set to the next and should thus be examined along with the political, cultural and economic issues. The manufacturing companies in Libya should keep themselves aware of the different accounting standards determinants in order to concentrate on the MA use in the present economy in the country following the revolution of 2011 (Abou-Alkheir, 2016). The Libyan market environment is ripe one to examine MA under an environment that is characterized by uncertainty and political change.

\section{Objectives}

The main objective is to develop a reliable instrument to measure management accounting tools through Exploratory Factor Analysis in Libyan manufacturing companies.

\section{Literature Review}

Management accounting tools, also known as management accounting practices (MAPs) refer to management tools or methods used to bring about decisions concerning operations/activities (Rufino, 2014). They are useful in every organization, whether or not they are profit-oriented. It is a must for every business organization to adoption management accounting tools notwithstanding their size, operation or market and among the three business operation types that should take advantage of such tools are service, merchandising and manufacturing.

Many studies developed the adoption, benefits, and the obstacles to the implementing of MATs ( e.g. Angelakis et al., 2010; Albu \& Albu, 2012; Yap et al., 2014; Sreekumar, 2015; Ladislav, 2016; Cuzdriorean, 2017; Hussein, 2017; Azudin \& Mansor, 2017). Chenhall \& Langfield-Smith (1998); Angelakis et al (2010); Hussein (2017) conducted examinations of the MATs adoption and the reaped benefits in Australia, Greece and Egypt respectively. They categorized the tools into five (long-term planning, budgeting systems, product costing, performance evaluation and decision support systems). In Malaysia Tun Mat and Smith, (2014); Azudin \& Mansor (2017) lists sixteen MATs from four stages of the management accounting evolution. Besides that, In search for additional explanations of why the large majority of MATs addressed are not adopted and used, according to studies Yap et al (2014), Cuzdriorean (2017); Hussein, (2017), the respondents asked to indicate the extent to which a list of items obstacles the adoption of MATs.

\section{Exploratory Factor Analysis (EFA)}

This type of analysis was described by Awang (2012), and Shkeer \& Awang (2019) as a strategy employed to determine the development of a group of factors gathering. It is a measurable method used to achieve data summarizing and data reduction (Tabachnick \& Fidell, 2013). In 
other words, EFA is a method used for the recognition, minimization and organization of a large number of survey items into a specific construct for the examination of the independent construct.

Scientists are of the consensus as the use of EFA process on each variable to detect the objects dimensionality from the previous studies, where the measurements originated. In this regard, the items dimensionality may transform when the examination that is current carried out is different from those that were carried out in the past based on the study field, country and monetary situation of the population (Awang, 2012; Noor et al., 2015; Hoque et al., 2018). Another added factor is the period between the current investigation and the past ones in literature - the outcomes in the past may not be relevant owing to the referenced distinctions mentioned above (Awang, 2012; 2014). The respondents number for the pilot test $\mathrm{N}$ this study is 100 , and they were randomly chosen from the manufacturing firms in Libya.

\section{The Exploratory Factor Analysis Procedure}

The EFA procedure is initiated with a Kaiser-Meyer-Olkin (KMO) test and Bartlett's Test of Sphericity in order to confirm that the gathered data is appropriate to be exposed to factor analysis. The two tests basically gauge the sampling adequacy to determine the factorability of the data index (Hair et al., 2014). In cases where the Bartlett's Test of Sphericity is significant and substantial, the KMO measure exceeds 0.50 , and has a tendency to accept the existence of the factorability of dataset (Pallant, 2016). The next step involves the use of Principal Component Analysis (PCA) extraction method with Varimax Rotation to differentiate the basic factors. The PCA is used to determine the number of factors to be included, while the Varimax Rotation is employed as a suitable orthogonal factor rotation method that sheds light in the elements examination (Hair et al., 2014).

Added to the above, Varimax Orthogonal technique has been evidenced to be effective in dealing with and getting the orthogonal rotation of factors. EFA is used to determine the underlying items scopes and eradicate those that remain under 0.60 cut-off of the factor loading, implying that factor loading that is less than 0.60 is unacceptable (Awang, 2014; 2015). A higher factor loading was brought forward by Bahkia et al. (2019), who stated that loadings under 0.30 should not be interpreted, and based on the general rule of thumb, 0.32 loadings are poor, 0.45 loadings are fair, 0.55 loadings are good, 0.63 loadings are very good, while 0.71 loadings are considered as excellent.

\section{Research Methodology}

This study randomly selected 100 financial managers / accountants in Libyan manufacturing companies from the total of 492 companies to be used as simple random sampling. The number of samples is adequate for the purpose of doing an Exploratory Factor Analysis (EFA) study (Hair, et al., 2016). According to Chenhall \& Langfield-Smith (1998); Angelakis et al (2010); Yap et al (2014); Hussein (2017), the MATs construct measured by three subconstructs (Adoption, benefits, and the obstacles to the use of MATs). The researcher adapted all the three sub-constructs to measure the MATs construct to conform to the study in the Libyan context.

The adoption, and benefits sub-constructs, using the same instrument applied by Laitinen (2006); Angelakis et al (2010); Mat \& Smith (2014); Azudin \& Mansor (2017), used the list of sixteen MATs. A list of sixteen MATs and developed survey questions to determine the adoption rate and the degree of importance for each tool. All sixteen of the Adoption, benefits sub construct showed sufficient reliability; which is greater than 0.7 and exhibited construct 
and discriminant validity Angelakis et al (2010). The researcher adapted all sixteen tools to the Adoption, benefits sub construct to conform to the study in Libyan context.

In addition, for the obstacles to the use of MATs sub-construct, using the same instrument applied by Hussein (2017) the obstacles to the use of MATs sub-construct has nine items, all items showed sufficient reliability; which is greater than 0.7 and exhibited construct and discriminant validity Hussein (2017). The researcher adapted all times to conform to the study in the Libyan context. The respondents were asked to indicate the Adoption sub construct by using sixteen items (1-16) in the questionnaire. Respondents were asked on a five-point Likert scale of 1 (never used) to 5 (very often) to measure the adoption sub construct. And Benefits sub construct was measured by using sixteen items (1-16) in the questionnaire a five-point Likert scale of 1 (None) to 5 (Very high) to measure the benefits sub construct.

Under this part, also, the respondents were asked to indicate the obstacles to the use of MATs in Libyan manufacturing firms (especially those who answer never use ) by using ten items (19 ) in the questionnaire. Respondents were asked on a five-point Likert scale of " 1 ")(Do not impede at all) to " 5 " (Considerably impede) to measure the obstacles to the use of MATs in Libyan manufacturing firms. The questionnaire was then piloted on a small sample size before the actual survey - this involved 10 Libyan employees working in the manufacturing firms, after which eight questionnaires from the ten distributed ones were retrieved and scrutinized for resolution of issues, if any. No issues were found and thus, the questionnaire was deemed to be ready for the pilot study.

\section{Exploratory Factor Analysis for Management Accounting Tools}

In the questionnaire, there are 41 measurement items measuring MATs. Three sub-constructs initially measured the MATs constructs: (1)(Adoption, (2)benefits, and (3) the obstacles to the implementing of MATs. The Adoption and benefits dimensions have sixteen items each, obstacles to the implementing of MATs has nine items.

The descriptive statistics of each item are tabulated in Table 1 and they are measured using a five-point Likert scale of 1 (never used) to 5 (very often), (None) to (Very high), and (Do not impede at all) to (Considerably impede) respectively adopted from Awang et al (2016) and Hoque et al (2018). Table 1 contains the statements of items and their mean and standard deviation scores. 
Table 1: The Mean and Standard Deviation for Items Measuring Management Accounting Tools

\begin{tabular}{|c|c|c|c|}
\hline \multicolumn{4}{|c|}{ Descriptive Statistics } \\
\hline & Item Statement & Mean & $\begin{array}{l}\text { Standard } \\
\text { Deviation }\end{array}$ \\
\hline 1 & Budgetary Control & 4.090 & .697 \\
\hline 2 & Full/ Absorption Costing & 4.000 & .828 \\
\hline 3 & Cost-volume-profit (CVP) analysis & 3.930 & .781 \\
\hline 4 & Marginal/ Variable Costing & 4.040 & .777 \\
\hline 5 & Standard Costing & 4.010 & .771 \\
\hline 6 & Total Quality Management (TQM) & 4.040 & .777 \\
\hline 7 & Target Costing & 3.980 & .765 \\
\hline 8 & Activity Based Costing (ABC) & 3.960 & .827 \\
\hline 9 & Activity Based Management (ABM) & 3.890 & .827 \\
\hline 10 & Value Chain Analysis & 3.970 & .744 \\
\hline 11 & Product Life Cycle Analysis & 4.090 & .697 \\
\hline 12 & Benchmarking & 4.010 & .731 \\
\hline 13 & Product Profitability Analysis & 3.960 & .803 \\
\hline 14 & Customer Profitability Analysis & 4.030 & .784 \\
\hline 15 & Shareholder Value Analysis/ EVA & 4.020 & .828 \\
\hline 16 & Balanced Scorecard & 3.960 & .827 \\
\hline 17 & Budgetary Control & 3.820 & .716 \\
\hline 18 & Full/ Absorption Costing & 3.590 & .865 \\
\hline 19 & Cost-volume-profit (CVP) analysis & 3.600 & .864 \\
\hline 20 & Marginal/ Variable Costing & 3.620 & .788 \\
\hline 21 & Standard Costing & 3.840 & .761 \\
\hline 22 & Total Quality Management (TQM) & 3.870 & .719 \\
\hline 23 & Target Costing & 3.660 & .699 \\
\hline 24 & Activity Based Costing (ABC) & 3.860 & .765 \\
\hline 25 & Activity Based Management (ABM) & 3.940 & .776 \\
\hline 26 & Value Chain Analysis & 3.860 & .738 \\
\hline 27 & Product Life Cycle Analysis & 3.630 & .895 \\
\hline 28 & Benchmarking & 3.730 & .750 \\
\hline 29 & Product Profitability Analysis & 3.900 & .771 \\
\hline 30 & Customer Profitability Analysis & 3.930 & .794 \\
\hline 31 & Shareholder Value Analysis/ EVA & 3.850 & .770 \\
\hline 32 & Balanced Scorecard & 3.890 & .750 \\
\hline 33 & Headquarters and government regulations & 3.930 & .843 \\
\hline 34 & $\begin{array}{l}\text { Cadres that implement the of management accounting } \\
\text { tools are not qualified }\end{array}$ & 4.040 & .839 \\
\hline 35 & $\begin{array}{l}\text { Costs of the application of management accounting } \\
\text { tools are relatively high }\end{array}$ & 4.060 & .814 \\
\hline 36 & $\begin{array}{l}\text { Senior management is not convinced by the of } \\
\text { management accounting tools }\end{array}$ & 4.050 & .783 \\
\hline 37 & $\begin{array}{l}\text { Software required by the application of management } \\
\text { accounting is not available }\end{array}$ & 3.970 & .869 \\
\hline
\end{tabular}




\begin{tabular}{llllc}
\hline 38 & $\begin{array}{l}\text { The information system is not developed enough to the } \\
\text { optimal application of management accounting tools }\end{array}$ & 4.050 & .821 \\
\hline 39 & $\begin{array}{l}\text { Lack of relevant courses on such advanced techniques } \\
\text { in academic institutions }\end{array}$ & 4.000 & .791 \\
\hline 40 & $\begin{array}{l}\text { Lack of up-to-date publications about advanced } \\
\text { management accounting tools }\end{array}$ & 3.950 & .880 \\
\hline 41 & Company ownership type & 4.050 & .821 \\
\hline
\end{tabular}

The present study employed EFA, Principal Component Analysis, with Varimax Rotation on the 41 measurement items of MATs and the results from the test are tabulated in Table 2. From the table, it is clear that Bartlett's Sphericity Test is significant ( $p$-value $<0.05$ ), sampling adequacy by KMO (0.748) is excellence, because it is higher than 0.6 (Awang, 2012; Hoque et al., 2015; Noor et al., 2015). Both results are indicative of the adequacy of data for further data reduction analysis (Awang, 2012; Noor et al., 2015; Hoque \& Awang, 2016; Hoque et al., 2017, 2018; Yahaya et al., 2018).

Table 2: KMO and Bartlett's Sphericity Test Results for MATs Construct

\begin{tabular}{lll}
\hline KMO and Bartlett's Test \\
\hline \multicolumn{3}{l}{ Kaiser-Meyer-Olkin Measure of Sampling Adequacy. } \\
\hline Bartlett's Test & of Approx. Chi-Square & .748 \\
\cline { 2 - 3 } Sphericity & Df & 137.605 \\
\cline { 2 - 3 } & Sig. & .005 \\
\hline
\end{tabular}

Figure 1 presents a scree plot of the three dimension/components that EFA procedure obtained for the MATs construct. All 41 items were grouped into three dimensions, with each dimension having its own items set. The accurate determination of which items belong to which component is determined using the Rotated Component Matrix (Awang, 2012). 


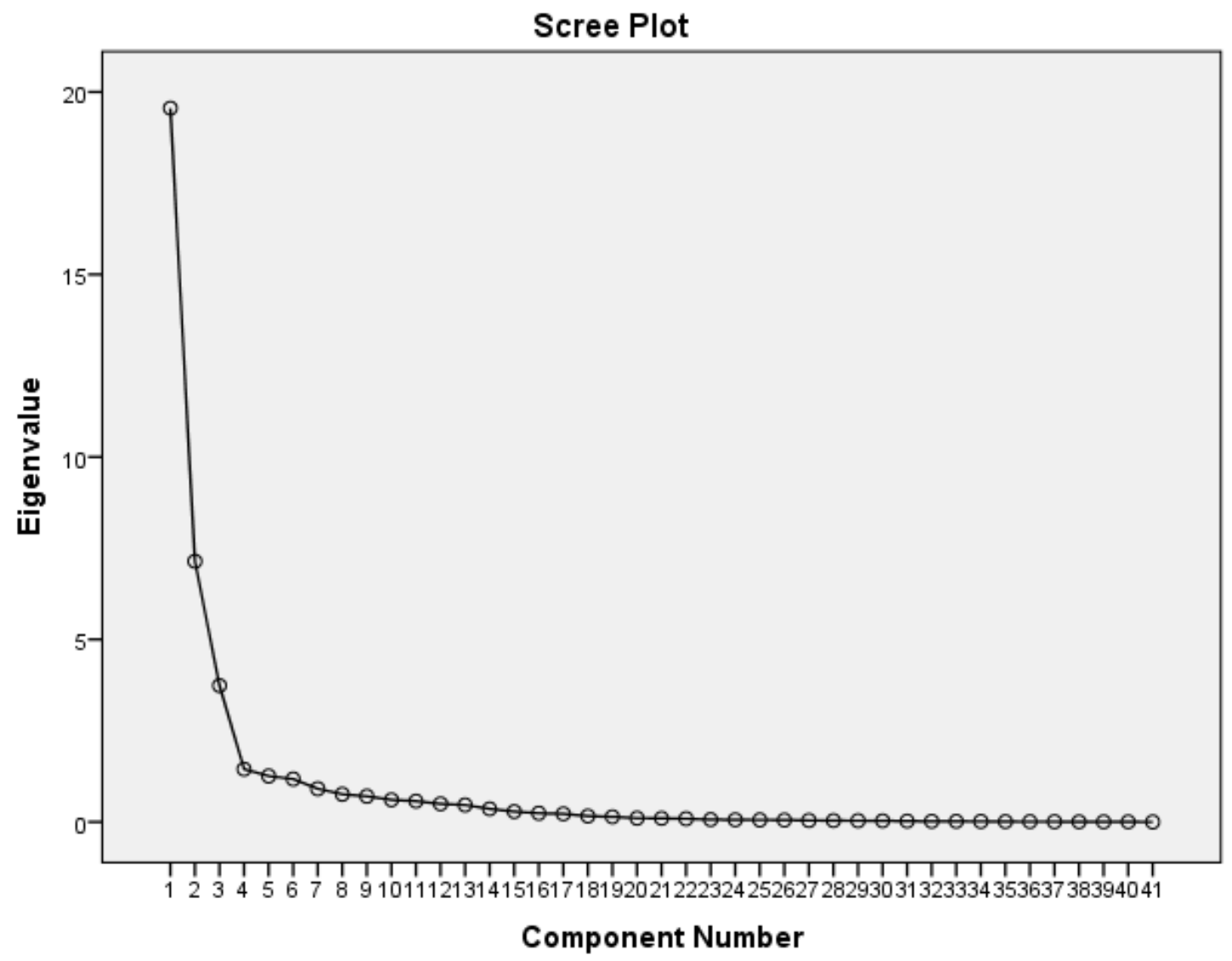

\section{Figure 1 Scree Plot for MATs}

Three dimensions were obtained from the EFA procedure of MATs based on the Eigen value higher than 1.0. Specifically, the Eigen values varied from 3.648 to 19.557 . For component 1 , the variance explained is $30.194 \%$, for component 2 , it is $56.636 \%$, and lastly, for component 3 , it is $76.031 \%$. Moreover, the total variance explained for the construct measurement is $76.031 \%$, and was deemed acceptable as it exceeded the minimum value of $60 \%$ (Awang, 2012; Noor et al., 2015; Hoque \& Awang, 2016; Hoque et al., 2017, 2018; Yahaya et al., 2018).

Table 3: Total Variance Explained for MATs Construct

\begin{tabular}{|c|c|c|c|c|c|c|c|c|c|}
\hline \multicolumn{10}{|c|}{ Total Variance Explained } \\
\hline \multirow{3}{*}{$\begin{array}{l}\frac{U}{c} \\
d \\
0 \\
0 \\
\stackrel{0}{\varepsilon} \\
0 \\
0\end{array}$} & \multicolumn{3}{|c|}{ Initial Eigenvalues } & \multicolumn{3}{|c|}{$\begin{array}{l}\text { Extraction Sums of Squared } \\
\text { Loadings }\end{array}$} & \multicolumn{3}{|c|}{$\begin{array}{l}\text { Rotation Sums of Squared } \\
\text { Loadings }\end{array}$} \\
\hline & & $\% \quad$ of & & & & & & $\%$ & \\
\hline & Total & $\begin{array}{l}\text { Varianc } \\
\mathrm{e}\end{array}$ & $\begin{array}{l}\text { Cumulativ } \\
\text { e \% }\end{array}$ & Total & $\begin{array}{l}\text { Varianc } \\
\mathrm{e}\end{array}$ & $\begin{array}{l}\text { Cumulativ } \\
\text { e \% }\end{array}$ & Total & $\begin{array}{l}\text { Varianc } \\
\mathrm{e}\end{array}$ & $\begin{array}{l}\text { Cumulativ } \\
\text { e \% }\end{array}$ \\
\hline 1 & $\begin{array}{l}19.55 \\
7\end{array}$ & 47.700 & 47.700 & $\begin{array}{l}19.55 \\
7\end{array}$ & 47.700 & 47.700 & $\begin{array}{l}12.37 \\
9\end{array}$ & 30.194 & 30.194 \\
\hline 2 & 7.141 & 16.168 & 69.045 & 7.141 & 16.168 & 69.045 & $\begin{array}{l}10.84 \\
1\end{array}$ & 26.442 & 56.636 \\
\hline 3 & 3.648 & 8.897 & 77.942 & 3.648 & 8.897 & 77.942 & 7.952 & 19.395 & 76.031 \\
\hline
\end{tabular}


One dimension emerged from the respective items of the EFA procedure in this construct (refer to Table 4), and every item should have a factor loading that is higher than 0.60 to remain in the analysis as proposed by Awang (2012) and Yahaya et al. (2018). Items that loaded lower than 0.60 should be discarded (Awang, 2012, 2014 \& 2015; Noor et al., 2015; Hoque \& Awang, 2016; Hoque et al., 2017, 2018; Yahaya et al., 2018). Table 4 tabulates the measurement items, their factor loadings and their respective components.

Table 4: Rotated Component Matrix for MATs Construct

\begin{tabular}{|c|c|c|c|}
\hline \multicolumn{4}{|c|}{ Rotated Component Matrix ${ }^{a}$} \\
\hline & \multicolumn{3}{|c|}{ Component } \\
\hline & 1 & 2 & 3 \\
\hline MATs1 & .889 & & \\
\hline MATs2 & .728 & & \\
\hline MATs3 & .785 & & \\
\hline MATs4 & .858 & & \\
\hline MATs5 & .858 & & \\
\hline MATs6 & .848 & & \\
\hline MATs7 & .830 & & \\
\hline MATs8 & .847 & & \\
\hline MATs9 & .739 & & \\
\hline MATs10 & .794 & & \\
\hline MATs11 & .889 & & \\
\hline MATs12 & .840 & & \\
\hline MATs13 & .760 & & \\
\hline MATs14 & .854 & & \\
\hline MATs15 & .802 & & \\
\hline MATs16 & .847 & & \\
\hline Ben1 & & .726 & \\
\hline Ben2 & & .746 & \\
\hline Ben3 & & .724 & \\
\hline Ben4 & & .721 & \\
\hline Ben5 & & .951 & \\
\hline Ben6 & & .632 & \\
\hline Ben7 & & .743 & \\
\hline Ben8 & & .943 & \\
\hline Ben9 & & .868 & \\
\hline Ben10 & & .671 & \\
\hline Ben11 & & .703 & \\
\hline Ben12 & & .727 & \\
\hline Ben13 & & .871 & \\
\hline Ben14 & & .859 & \\
\hline Ben15 & & .938 & \\
\hline Ben16 & & .627 & \\
\hline Obst1 & & & .835 \\
\hline Obst2 & & & .813 \\
\hline Obst3 & & & .816 \\
\hline Obst4 & & & .782 \\
\hline
\end{tabular}




$\begin{array}{ll}\text { Obst5 } & .847 \\ \text { Obst6 } & .846 \\ \text { Obst7 } & .829 \\ \text { Obst8 } & .856 \\ \text { Obst9 } & .844\end{array}$

Extraction Method: Principal Component Analysis.

\section{Internal Reliability Analysis (Cronbach's Alpha)}

Reliability test was the second test to be conducted after EFA. This test examines the inner consistency through the use of Cronbach's Alpha coefficient to ensure that the research instruments are devoid of random error and bias (Sekaran \& Bougie, 2016). Cronbach's alpha coefficient has been extensively utilized for estimating internal consistency and it runs from 0 to 1 (De Vaus, 2013), and is identified by the normal associations among the measurement items. Cronbach's alpha is also used to assess the consistency level between different variable estimations (Hair et al., 2014).

Therefore, this study used Cronbach's alpha coefficient to examine the MATs construct internal consistency. Following the pilot test, Cronbach's alpha was used for the purpose mentioned above as it is one of the most extensively utilized techniques to ensure reliability, with value of 0.70 and over deemed to illustrate adequate internal consistency reliability (Awang, 2012, 2015; Hair et al., 2016; Awang et al., 2015; Awang et al., 2018). Cronbach's alpha needs to be processes to determine the internal reliability of the items estimating the MATs construct.

The Internal Reliability for Management Accounting Tools

Table 5: Cronbach' Alpha for Internal Reliability for Management Accounting Tools Construct

\begin{tabular}{llll}
\hline Components & Sub-construct & No. of Items & Cronbach's Alpha \\
\hline 1 & Adoption MATs & 16 & .841 \\
\hline 2 & Perceived benefits & 16 & .833 \\
\hline 3 & Obstacles & 9 & .881 \\
\hline & Management Accounting Tools & 41 & .896 \\
\hline
\end{tabular}

The three dimensions that were used to estimate MATs obtained an alpha that exceeded 0.70, and Cronbach's alpha coefficient for all 41 items within the three dimensions is 0.896 , which also exceeded 0.70. Therefore, all the items measuring MATs were deemed to have sufficient internal reliability following prior studies (Awang, 2012, 2014, 2015; Hoque et al., 2018; Shkeer \& Awang, 2019). Reliability estimates for the three dimensions of MATs were way above the cut-off alpha coefficient value and thus, they were considered to be reliable and are appropriate to be used for estimating MATs.

\section{Conclusion}

At this point of the study, EFA was independently conducted for the MATs construct. SPSS, version 24 was used for the analysis. The results show that the MATs construct has three components or dimensions: (1)(Adoption, (2)benefits, and (3) the obstacles to the implementing of MATs. The Adoption and benefits dimensions have sixteen items each, obstacles to the implementing of MATs have nine items. All reliability measures for the three dimensions or components of the MATs construct showed high Cronbach's Alpha value, met Bartlett Test achievements (significant) at $p<0.001$ (Hair et al., 2016), KMO (>0.6), and exceeded 0.60 of factor loadings. 


\section{References}

Abou-Alkheir, M. (2016). Improving the Quality of Banking Decisions Using the Methods of Management Accounting. Journal of Economic and Political Sciences, No.8(4).

Ahmad, K., \& Zabri, S. M. (2015). Factors explaining the use of management accounting practices in Malaysian medium-sized firms. Journal of Small Business and Enterprise Development, 22(4), 762-781.

Albu, N., \& Albu, C. N. (2012), "Factors associated with the adoption and use of management accounting techniques in developing countries: the case of Romania", Journal of International Management \& Accounting, Vol. 23 No. 3, pp. 245-276.

Angelakis, G., Theriou, N., \& Floropoulos, I. (2010) "Adoption and benefits of management accounting practices: Evidence from Greece and Finland", Advances Accounting and Management Information Systems in Accounting, incorporating Advances in International Accounting, vol. 26: 87-96.

Asnawi, A., Awang, Z., Afthanorhan, A., Mohamad, M., \& Karim, F. (2019). The influence of hospital image and service quality on patients' satisfaction and loyalty. Management Science Letters, 9(6), 911-920.

Awang, Z. (2012). Research methodology and data analysis. Penerbit Universiti Teknologi MARA Press. Malaysia.

Awang, Z. (2014). A handbook on SEM for academicians and practitioners: the step by step practical guides for the beginners. Bandar Baru Bangi, MPWS Rich Resources.

Awang, Z. (2015). SEM made simple: A gentle approach to learning Structural Equation Modelling. Bandar Baru Bangi, MPWS Rich Resources.

Awang, Z., Afthanorhan, A., Mohamad, M., \& Asri, M. A. M. (2015). An evaluation of measurement model for medical tourism research: the confirmatory factoranalysis approach. International Journal of Tourism Policy, 6(1), 29-45.

Awang, Z., Afthanorhan, W. M. A. W., \& Asri, M. A. M. (2015a). Parametric and non- parametric approach in structural equation modeling (SEM): The application of bootstrapping. Modern Applied Science, 9(9), 58.

Awang, Z., Afthanorhan, A., \& Mamat, M. (2016). The Likert scale analysis using parametric based Structural Equation Modeling (SEM). Computational Methods in Social Sciences, 4(1), 13-21.

Awang, Z., Lim, S. H., \& Zainudin, N. F. S. (2018). Pendekatan mudah SEM-Structural Equation Modelling. Bandar Baru Bangi, MPWS Rich Resources.

Awang, Z., Rahlin, N. A., \& Afthanorhan, A. (2019). Conceptual Framework for Best Practices of Behavior-Based Safety Performance Evaluation in SME. Journal of Applied Engineering Science, 17(4).

Azudin, A., \& Mansor, N. (2017). Management accounting practices of SMEs: The impact of organizational DNA, business potential and operational technology, Asia Pacific Management Review.

Bahkia, A. S., Awang, Z., Afthanorhan, A., Ghazali, P. L., Foziah, H. (2019). Exploratory Factor Analysis on occupational stress in context of Malaysian sewerage operations AIP Conference Proceedings.

Chenhall, R. H., \& Langfield-Smith, K. (1998). Factors influencing the role of management accounting in the development of performance measures within organizational change programs. Management Accounting Research, 9(4), 361-386.

CIMA. (2013). Essential tools for management accountants - the tools and techniques to support sustainable business success. https://www.cgma.org/content/dam/cgma/ 
resources/tools/essential-tools/downloadabledocuments/essential-tools-for management-accountants.pdf.

Cuzdriorean, D. D. (2017), The Use of Management Accounting Practices by Romanian Small and Medium-Sized Enterprises: A Field Study, Accounting and Management Information Systems Vol. 16, No. 2, pp. 291-312.

De Vaus, D. (2013). Surveys in social research. Routledge.

Ghorbel, J. (2016). The Relationship between the Profile of Manager and Management Accounting Practices in Tunisian SMIs. International Journal of Academic Research in Accounting, Finance and Management Sciences, 6(1), pp. 61-72.

Hair, J., Hult, T., Ringle, C., \& Sarstedt, M. (2014). A primer on Partial Least Squares Structural Equation Modeling (PLS-SEM). Thousand Oaks, CA Sage.

Hair, J., Hult, T., Ringle, C., \& Sarstedt, M. (2016). A Primer on Partial Least Squares Structural Equation Modeling (PLS-SEM). 2nd Ed.). London: SAGE Publications.

Hieu, P., \& Dung, B. (2018). Management Accounting Practices in Vietnam: An Empirical Study, Account and Financial Management Journal, Vol 3 , P No. 1616-1620.

Hoque, A. S. M. M., \& Awang, Z. (2016). The Exploratory Factor Analysis (EFA) of entrepreneurial marketing scale: Development and validation. Tourism Conference 2022 April 2016 (p. 22).

Hoque, A. S. M. M., Awang, Z., Jusoff, K., Salleh, F., \& Muda, H (2017). Social business efficiency: Instrument development and validation procedure using Structural Equation Modelling. International Business Management, 11(1), 222- 231.

Hoque, A. S. M. M., Siddiqui, B. A., Awang, Z. B., \& Baharu, S. M. A. T. (2018). Exploratory Factor Analysis of entrepreneurial orientation in the context of Bangladesh small and medium enterprises (SMES). European Journal of Management and Marketing Studies.

Hussein, A. (2017). Adoption, Importance and Barriers to the Implementation of Contemporary Management Accounting Practices: Evidence from Egypt. Accounting and Finance Research, Vol. 7, No. 1; 2018.

Ladislav, S. (2016), The Contingency Factors Affecting Management Accounting in Czech Companies. Acta Universities Agriculturae et Silviculturae Mendelianae Brunensis, 64(4): 1383-1392.

Laitinen, E. K. (2006). Explaining management accounting change: Evidence from Finland. International Journal Accounting, Auditing and Performance Evaluation, 3(2), 252281.

Mohamad, M., Afthanorhan, A., Awang, Z., \& Mohammad, M. (2019). Comparison between CB-SEM and PLS-SEM: Testing and confirming the Maqasid Syariah quality of life measurement model. Journal of Social Science Research. Open Access. Vol. 5 No. 3, Pages 608-614.

Noor, N. M., Aziz, A. A., Mostapa, M. R., \& Awang, Z. (2015). Validation of the Malay version of the inventory of functional status after childbirth questionnaire. BioMed research international, 2015.

Sekaran, U. (2013) Research methods for business : a skill-building approach. 6th ed. / Uma Sekaran.. edn. Hoboken, N.J.: Hoboken, N.J. : Wiley.

Shkeer, A. S., \& Awang, Z. (2019). Exploring Items for Measuring Marketing Information System Construct: An Exploratory Factor analysis. International Review of Management and Marketing, 9(6), 87-97. 
Sreekumar, K. (2015). Management Accounting Practices and Organizational Performance : a Study of Environmental and Organizational Antecedents As Perceived By Finance and Accounting Managers, (August 2015).

Sumkaew, N. (2016). Management accounting changes and the interaction effect of management accounting practices and integrated information systems on organizational performance: evidence from Thailand (Doctoral dissertation, Newcastle University).

Tabachnick, B. G., \& Fidell, L. S. (2013). Using multivariate statistics. Pearson New International Edition.

Mat, T. Z., Smith, M., \& Djajadikerta, H. (2010) 'Management Accounting and Organisational Change: An Exploratory Study in Malaysian Manufacturing Firms', Journal of Applied Management Accounting Research, 8(2), pp. 51-80.

Mat, T., Zainun, T., \& Smith, M. (2014). The Impact of Changes in Environment and AMT on Management Accounting Practices and Organizational Strategy, Structure and Performance. Journal of Applied Management Accounting Research, 12(1).

Rufino, H. D. (2014). Management Accounting Practices (MAPs) of Small and Medium-sized Manufacturing Enterprises in The City of Tarlac. Review of Integrative Business Economic Research Vol. 4(1).

Pallant, J. S. P. S. S. (2016). Survival manual: A step by step guide to data analysis using SPSS program. London: McGraw-Hill.

Yahaya, T., Idris, K., Suandi, T., \& Ismail, I. (2018). Adapting instruments and modifying statements: The confirmation method for the inventory and model for information sharing behavior using social media. Management Science Letters, 8(5), 271-282.

Yap, K., Lee, T., Said, J., \& Yap, S. (2013). Adoption, Benefits and Challenges of Strategic Management Accounting Practices: Evidence from emerging market. Asia Pacific Management Accounting Journal, 8(2). 